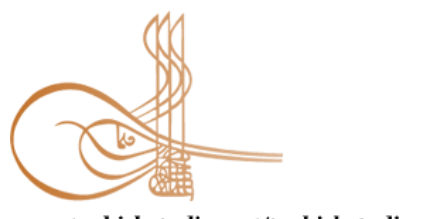

www.turkishstudies.net/turkishstudies

\section{Turkish Studies}

eISSN: $1308-2140$

Research Article / Araștırma Makalesi

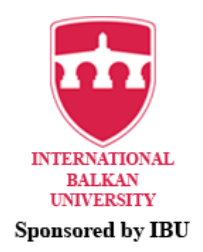

Sponsored by IBU

\title{
Covid-19 Pandemi Döneminde Hanehalkındaki Çatışma ve Birlik-Beraberlik Durumunun İncelenmesi
}

\author{
Examination of Conflict and Cohesion Situation in Household During Covid-19 Pandemic Period
}

\author{
M. Serhat Öztürk ${ }^{*}$ - Nihan Yılmaz ${ }^{* *}$ - Didem Demir Erbil ${ }^{* * *}$ - Oya Hazer ${ }^{* * * *}$
}

\begin{abstract}
This study was planned and carried out to investigate the activities affecting the conflict and cohesion situation that could occur in the relations of household members with the effect of the Covid-19 pandemic, which affects the whole world. Considering the importance of Covid-19 in the literature, which does not have much information about it, the data on the conflict and cohesion status of household members; It is considered important to give valid suggestions to individuals, society and state authorities and to establish long-term policies. Before starting the study, the approval of the ethics committee numbered 35853172-200 was obtained at the meeting of Hacettepe University Ethcis Committee on June 23,2020. The Covid-19 Household Environment Scale (CHES) developed by Chaves and Gattamorta (2020) was used to determine the effect of Covid-19 in the household environment. CHES consists of 2 parts. In the first part, there are questions to determine the demographic characteristics of the participants, the composition of the household (information about the household) and at the household level, there are questions to identify problems encountered in health and work life during the Covid-19 pandemic period. In the second part, there are various activities that determine conflict and cohesion level during the Covid-19 pandemic period and before. The Cronbach's alpha internal consistency coefficient of the two-dimensional scale is 1 st dimension $\alpha=.894$, 2nd
\end{abstract}

*Dr. Öğr. Üyesi, Hacettepe Üniversitesi, İktisadi ve İdari Bilimler Fakültesi, Aile ve Tüketici Bilimleri Bölümü Assist. Prof., Hacettepe University, Faculty of Economics and Administrative Sciences, Department of Family and Consumer Sciences

ORCID 0000-0002-7285-983X

sozturk@hacettepe.edu.tr

** Arş. Gör. Dr., Hacettepe Üniversitesi, İktisadi ve İdari Bilimler Fakültesi, Aile ve Tüketici Bilimleri Bölümü

Res. Assist. Dr. Hacettepe University, Faculty of Economics and Administrative Sciences, Department of Family and Consumer Sciences

ORCID 0000-0002-2451-0852

nihangursoy@ hacettepe.edu.tr

**** Doktora Öğrencisi, Hacettepe Üniversitesi, İktisadi ve İdari Bilimler Fakültesi, Aile ve Tüketici Bilimleri Bölümü PhD Student, Hacettepe University, Faculty of Economics and Administrative Sciences, Department of Family and Consumer Sciences

ORCID 0000-0003-2174-8184

didemdemir@hacettepe.edu.tr

***** Prof. Dr., Hacettepe Üniversitesi, İktisadi ve İdari Bilimler Fakültesi, Aile ve Tüketici Bilimleri Bölümü

Prof. Dr., Hacettepe University, Faculty of Economics and Administrative Sciences, Department of Family and Consumer Sciences

ORCID 0000-0002-0380-6865

ohazer@hacettepe.edu.tr

Cite as/ Atıf: Öztürk, M. S., Yılmaz, N., Demir Erbil, D., Hazer, O. (2020). Covid-19 pandemi döneminde hanehalkındaki çatışma ve birlik-beraberlik durumunun incelenmesi. Turkish Studies, 15(4), 295-314. https://dx.doi.org/10.7827/TurkishStudies.44424

Received/Geliş: 22 June/Haziran 2020

Accepted/Kabul: 10 August/Ağustos 2020

Copyright $(\mathrm{C}$ MDE, Turkey

Checked by plagiarism software

Published/Yayın: 30 August/Ağustos 2020

CC BY-NC 4.0 
dimension $\alpha=.916 .372$ household members from different provinces (46 provinces) of Turkey participated in the study. The mean levels of conflict status of household individuals $(39.55 \pm 16.50)$ and the mean levels of cohesion (42.22 \pm 17.22$)$ indicate that both conflict and cohesion increased slightly above the average level compared to before the pandemic. However, when looking at the difference in scores between household dimensions, it was seen that the cohesion status in the household during Covid-19 pandemic was higher than the conflict situation. While there was a significant difference between the age groups of participants, marital status, child status at home, the total number of people living at home, the status of one of the household members having Covid-19 symptoms, duration of household members maintaining social distance and their conflict scores, only a significant difference was found in the participants' perceived level of income and their cohesion scores.

\section{Structured Abstract: Purpose}

In addition to treating health as a medical issue, it is necessary to consider its social, psychological, social and individual dimensions in order to succeed both in the short and long term in terms of epidemic. Considering its importance in the literature, it is aimed to reveal the data examining the effect of Covid-19, which does not have much information, on the conflict and cohesion situations of household members; it is considered important to give valid recommendations to individual, community and state authorities and to establish long-term policies. In this context, this study was planned and carried out to investigate the activities that affect the conflict and cohesion situation that could occur in the relations of household members with the effect of the Covid-19 epidemic.

\section{Method}

In the research, quantitative research method was chosen as the data collection method and online questionnaire was chosen as the data collection tool. The reason for choosing the online data collection method in the study is that the method enables the results to be obtained in a shorter time and the subjects can fill the data collection tool in the most convenient time slice. In order to implement the study, Hacettepe University Ethics Committee approval was obtained. The survey of "Investigation of Conflict and Cohesion Situation in Household During Covid-19 Pandemic Period" prepared through "Google Forms" was applied online to household members over the age of 18 between June 23 and July 10, 2020. With the online survey it is easier to reach households living in different cities. 372 household members from different provinces of Turkey participated in this study. (46 provinces)

Covid-19 Household Environment Scale (CHES) consists of 2 parts. In the first part, there are questions to determine the demographic characteristics of the participants, the composition of the household (information about the household) and the problems encountered in the health and working life of the household during the Covid-19 pandemic period.

In the second part, there are various activities that determine the conflict and cohesion status of the household in the Covid-19 pandemic period and before. The scale consists of 2 sub-dimensions (Household Conflict and Household Cohesion), each consisting of 15 items. The items were rated on a 5-point scale. (Same as before: 1, Much less than before: 2, A little less than before: 3, A little more than before: 4, Much more than before: 5) In both sub-dimensions (Household conflict and Household cohesion), participants can get a minimum of 15 and a maximum of 75 points. As the scores increase for household conflict, the level of household conflict increases. Similarly, as the score for household cohesion increases, the level of cohesion increases.

The reliability of the scale was calculated with the internal consistency (Cronbach's Alpha) coefficient. The Cronbach's Alpha coefficient of the scale was measured as the conflict sub-dimension (0.89), the cohesion subscale $(0.91)$ and the total of the scale $(0.92)$.

\section{Discussion and Results}

In the research carried out to examine the activities that affect the conflict and cohesion situation that may occur in the relations of household members with the effect of the Covid-19 outbreak; it has been observed that the majority of household members have been maintaining social distance for more than 2 months, while almost all of them have maintained social distance. 
It was found that the rate of people working in a job with a high risk of Covid-19 contamination was slightly more than a quarter of the participants; a little more than half of the household members were working from home during the Covid-19 pandemic; one of the 10 people who participated in the study had to quit.

In the study, when the average of the conflict status and the level of cohesion of the household members is examined, it was determined that both the conflict and cohesion increased slightly above the middle level compared to before the pandemic. However, when we look at the difference in score between household environment dimensions, it was seen that the cohesion was higher than the conflict in the household during Covid-19 pandemic.

In this pandemic process, where social distance is maintained and spiritually challenging; it is an expected result that family cohesion situations will increase according to the conflict situation. As a result of the increase in the length of time in the activities and areas shared before the pandemic, the increase in cohesion is also a normal finding.

In the study, the presence of Covid-19 symptoms in one of the household members and the time of keeping the social distance of the household members differed significantly in terms of conflict. In families with Covid-19 symptoms conflict is higher in than those without symptoms. This worrying and stressful process is likely to cause conflicts in the household.

In the study, it was observed that the conflict decreased as the time to maintain social distance increased. In addition, during the Covid-19 period; It was determined that those who work in a job with a high risk of Covid-19, those who work from home during this period, those who do not work in the health sector, and those who have relatives who died due to Covid-19 have high unity and solidarity within the household.

When the changes in households' conflict activities in Covid-19 period compared to previous periods are examined; conflict has increased in personal hygiene $(58,6 \%)$ and health protection (eg taking medications on time, visiting a doctor, eating enough) $(54,0 \%)$ compared to previous periods. It can be estimated that the increase in conflicts regarding personal hygiene and health protection compared to previous periods is caused by the occasional information pollution in the society about Covid-19 (especially on the websites).

Other issues that appear to have increased conflict in the study are household chores (eg cleaning or ordering of the house, laundry, ironing etc.) (56.2\%) and food preparation (eg what to buy, what foods to cook or how much to eat) $(54,3 \%)$. It seems that women, especially in this period, cooking, cleaning the house, taking care of children, and the activities are uninterrupted, are reflected in the household as a multiple role conflict.

It has been determined that there is no difference in the case of conflict regarding the protection of privacy $(36.3 \%)$, parenting or child care, $(33.6 \%)$ and politics $(32.0 \%)$ compared to previous periods.

Going out of the house (eg work, appointment, visits) (34.6\%), guests coming home (31.2\%), and alcohol, tobacco or drug use $(23.7 \%)$ during the Covid-19 period it creates activities with little conflict.

It is observed that activities of spending leisure time together (e.g., hobbies, television, playing games, social media) (61.3\%), sharing household chores (e.g. cooking, gardening, laundry, cleaning) (60.7\%), helping each other (for example, with the use of technology and health needs) (60.2\%) and engaging in conversation (60.0) increased more than the previous period.

Contributing to the cohesion of household members in Covid-19 period; showing affection (hugging, embracing, kissing) (23.7\%), physical intimacy with the partner (22.4\%), exercising and doing sports together (17.7\%), and going on errands together (e.g. to the market or drugstore) (16.2\%) was found to decrease in activities compared to previous periods. It is seen that household members are in cohesion with regard to personal and physical contact in order to minimize the risk of Covid-19 contamination.

In light of all these results, the problems of the challenging Covid-19 pandemic process in families are revealed; In this regard, educational programs and practices, academic studies, projects and project supports to be established regarding the solution of problems and conflicts that may and may occur in households are very important.

Keywords: Family and Consumer Science, Covid-19, Pandemic, Social distance, Household, Conflict, Cohesion 
Öz: Bu çalışma, tüm dünyayı etkisi altına alan Covid-19 pandemisinin etkisiyle hanehalkı üyelerinin ilişkilerinde ortaya çıkması muhtemel çatışma ve birlik-beraberlik durumunu etkileyen faaliyetleri incelemek amacıyla planlanmış ve yürütülmüştür. Hakkında çok fazla bilgiye sahip olunmayan Covid-19'un literatürdeki önemi göz önüne alındığında, hanehalkı üyelerinin çatışma ve birlik/beraberlik durumları konusundaki verilerin ortaya konulmasının; birey, toplum ve devlet otoritelerine geçerli öneriler verilmesi ve uzun vadeli politikalar oluşturulması açıdan önemli olduğu düşünülmektedir. Araştırmaya başlamadan önce Hacettepe Üniversitesi Etik Kurulunun 23 Haziran 2020 tarihli toplantısında 35853172-200 sayılı etik kurul onay1 alınmıştır. Hanehaklı çevresindeki Covid-19 un etkisini belirlemek amacıyla Chaves ve Gattamorta (2020) tarafindan geliştirilen Covid-19 Hanehalkı Çevre Ölçeği (CHÇÖ) (Covid-19 Household Environment Scale (CHES) kullanılmıştır. Covid-19 Hanehalkı Çevre Ölçeği (CHÇÖ) 2 bölümden oluşmaktadır. İlk bölümünde katılımcıların demografik özelliklerini, hane halkı kompozisyonunu (hane halkına ilişkin bilgiler) ve hane halkı düzeyinde Covid-19 pandemi döneminde sağlık ve çalışma yaşamına ilişkin karşılaşılan sorunları belirlemeye yönelik sorular yer almaktadır. İkinci bölümde ise Covid-19 pandemi dönemi ve öncesindeki hanehalkı düzeyinde çatışma ve birlik/beraberlik durumunu belirleyici çeşitli faaliyetler yer almaktadır. İki boyuttan oluşan ölçeğin Cronbach's Alpha iç tutarlılık katsayısı 1.boyut $\alpha=.894$, 2.boyut $\alpha=.916$.' dır. Araştırmaya Türkiye'nin farklı illerinden (46 il) 372 hanehalkı üyesi katılmıştır. Hanehalkı bireylerinin çatışma durumu düzeyleri ortalamalarına $(39,55 \pm 16,50)$ ve birlik ve beraberlik durumu düzeyleri ortalamalarına $(42,22 \pm 17,22)$ bakıldığında hem çatışma hem de birlik/beraberlik durumlarının pandemi öncesine göre orta düzeyin biraz üstünde arttığı görülmektedir. Ancak hanehalkı çevresi boyutları arasındaki puan farkına bakıldığında ise, Covid-19 pandemi döneminde hanehalkındaki birlik ve beraberlik durumunun çatışma durumuna göre daha yüksek olduğu görülmüştür. Katılımcıların yaş grupları, medeni durum, evde yaşayan çocuk durumu, evde yaşayan toplam kişi sayısı, hanehalkı üyelerinin birinde Covid-19 belirtileri olma durumu ve hanehalk1 üyelerinin sosyal mesafeyi koruma süresi ile çatışma durumu arasında anlamlı bir farklılık bulunurken, katılımcıların sadece algılanan gelir düzeyi ile birlik ve beraberlik puanlarında anlamlı bir farklılık bulunmuştur.

Anahtar Kelimeler: Aile ve Tüketici Bilimleri, Covid-19, Pandemi, Sosyal mesafe, Hanehalkı, Çatışma, Birlik/beraberlik.

\section{Giriş}

Dünya Sağlık Örgütü, Covid-19 salgınını 30 Ocak’ta “uluslararası boyutta halk sağlığı acil durumu" olarak sınıflandırmış, salgının ilk başladığı Çin dışında 113 ülkede Covid-19 vakalarının görülmesi, virüsün yayılımı ve şiddeti nedeniyle 11 Mart'ta küresel salgın (pandemi) olarak tanımlamıştır (T.C. Sağlık Bakanlığı Halk Sağlığı Genel Müdürlüğü, 2020). Dünya Sağlık Örgütü, yayınlamış olduğu Covid-19 Strateji Güncelleme Raporu'nda (2020), pandeminin sıkıntılı zamanlarda güven duyulan geleneksel sosyal, ekonomik ve halk sağlığı ağlarının büyük bir bask1 altına girdiğini ifade ederek dünyanın her yerindeki birey, aile, topluluk ve toplumların hem yaşanan pandemi hem de pandemiye karşı alınan önlemlerden etkilendiği vurgulanmıştır (WHO,2020).

Ülkemizde Covid-19 ile ilgili çalışmalar 10 Ocak'ta başlamış ve 22 Ocak'ta T.C. Sağlık Bakanlığı Bilimsel Danışma Kurulu ilk toplantısı gerçekleştirilmiştir. İlk vakanın tespit edilmesinden bu yana geçen süreçte salgın ile ilgili olarak T.C. Sağlık Bakanlığı kademeli olarak salgının zararlarının azaltılması, salgının sınırlandırılması ve baskı altına alınması yönünde çalışmalarını başarıyla yürütmüştür (T.C. Sağlık Bakanlığı Halk Sağlığı Genel Müdürlüğü, 2020).

Covid-19 esas olarak damlacık yoluyla bulaşmaktadır. Ayrıca hasta bireylerin öksürme, hapşırma yoluyla ortaya saçtıkları damlacıklara diğer kişilerin elleri ile temas etmesi sonrasında ellerini ağız, burun veya göz mukozasına götürmesi ve temas etmesi ile bulaşmaktadır. Asemptomatik kişilerin solunum yolu salgılarında da virüs tespit edilebildiğinden bu kişiler bulaştırıcı olabilmektedir (T.C. Sağlık Bakanlığı Halk Sağlığı Genel Müdürlüğü, 2020).

Hastalığın insandan insana çok kolay ve hızlı bulaşabilme özelliği nedeniyle sosyal mesafe korunması uygulaması en etkili yöntem olarak tavsiye edilmiştir (Ferguson ve diğerleri, 2006) 
Salgını ortadan kaldırmak için değil ancak yayılma hızını yavaşlatmayı ve süreci yönetmekte olanlara zaman kazandırmayı amaçlayan bir tedbir olarak "sosyal mesafe" uygulaması, Covid-19 salgınını kontrol altına alacak bir aşı bulununcaya kadar, sağlık sistemi altyapısının çökmesini engellemek için gündeme getirilmiş bir tedbirdir (Özatay ve Sak, 2020a; Özatay ve Sak, 2020b)

Sosyal mesafe; mutlak izolasyonun zorunlu olmadığı, temasın ve etkene maruz kalmanın azaltılarak mümkün olan en düşük düzeyde tutulduğu yöntemdir. Bu durum insanların buluştuğu ya da toplandığı yerlerden uzak durmak, yerel toplu taşıma araçlarından (ör. otobüs, metro, taksi, birlikte binilen araba) kaçınmak ve diğer insanlarla temastan kaçınmak anlamına gelmektedir (Türkiye Psikiyatri Derneği, 2020).

Salgın sebebiyle ülkemizde sosyal mesafeyi korumak amacıyla okullarda yüz yüze eğitime ara verilmiş, boş zamanların değerlendirildiği alanlarda tedbir amaçlı faaliyetler durdurulmuş, kamu ve özel sektörde çalışanlara uzaktan çalışma, dönüşümlü çalışma gibi esnek çalışma yöntemleri uygulanmış, 65 yaş ve üzerindekiler ile 20 yaşın altındaki bireylere sokağa çıkma yasağı, tüm yaş gruplarına ise hafta sonları ve resmi tatillerde sokağa çıkma yasağı uygulanmış, seyahat kısıtlaması getirilmiştir.

Covid-19 salgını tüm dünyayı biyolojik, psikolojik, sosyal ve ekonomik açıdan etkisi altına almış ve hastalığın yayılmasının ardından toplumsal düzlemde hızlı bir dönüşüm süreci yaşanmaya başlamıştır. Pandeminin içeriği, yayılması, etki alanları ve önlenmesi konusunda sağlık bilimciler ilk günden itibaren önemli çalışmalar yürütmüşlerdir. Ancak salgının ardından oluşacak "yeni" toplumsal düzenin ne şekilde gerçekleşeceği ve insanlığı nelerin beklediği konusunda tahminler sınırlı kalmıştır. Sosyal mesafensin korunması bulaşıcı hastalık salgınlarında sıkça kullanılan bir müdahale olmasına rağmen, bir ailenin uzun süreli sosyal mesafeyi korumayı başarılı bir şekilde sürdürme yeteneğini neyin etkilediği hakkında çok az şey bilinmektedir.

Bireylerin evden çalışmaya başlaması, uzaktan eğitime geçilmesi ile (Gümüşgül ve Aydoğan, 2020) aynı konutta yaşayan bir ya da daha fazla kişiden oluşan hanehalkı üyeleri ev ortamında daha fazla zaman geçirmeye başlamış, iş, okul ve özel yaşam aynı yerde ve zamanda birleştirilmiş ve aile üyeleri her zamankine göre daha az bir alanda yaşamaya başlamıştır. Okul ve kreşlerin kapanması nedeniyle çalışan ebeveynlerin, özellikle de kadınların, evde bakım sorumlulukları önemli ölçüde artmıştır (NSPCC, 2020).

Alınan tedbirler doğrultusunda kişilerin evde kendisine, ailesine veya eş ve çocuklarına ayırdığı vakit büyük oranda artmıştır. İç yolculuğa daha fazla yönelinen, ilişkilerin gözden geçirildiği ve birçok yeniliğin keşfedildiği bu dönemde kimi ilişkiler olumlu kimi ise olumsuz etkilenmiştir. Hanehalkı içinde geçirilen bu dönem sadece sağlık için değil ilişkiler ve bireylerin kendisi için de mühim bir süreç haline gelmiştir. Kimi ailelerde gerginlikler artarken, kimi ailelerde birlik ve beraberlik ve dayanışma en üst düzeye ulaşmıştır.

Ortaya çıkan sorunların üstesinden gelmek ve dış tehdit karşısında insan doğasında olan, birlik ve dayanışma içinde olma, güçlerini birleştirme ve bağlanma ihtiyacı da artmaktadır (Kluwer, 2020). Birlik-beraberlik kavramı hanehalkı çevresinin kişiler arası boyutlarını belirleyen kavramlardan biridir (Usluer, 1989). Birlik-beraberlik, Moos (1974) tarafindan aile üyelerinin aile ile ne kadar ilgilendiği ve aile üyelerinin birbirlerine yardım etme ve destek olma derecesi olarak tanımlamıştır. Ayrıca Hampson ve Beavers'a (1993) göre aile üyelerinin birbirlerinin duygularına yönelik empati kurmaları ve anlaşılma beklentilerini içermektedir. Aile içindeki birlik-beraberlik alt boyutu, hanehalkı üyelerinin birbirleriyle olan duygusal bağlılığı șeklinde açıklanmaktadır. Ailenin kendi içinde sahip olduğu iletişim ve birlik-beraberlik karşılıklı olarak ekileşim içerisindedir. Çok yoğun yaşanan birlik-beraberlik duygusu, sağlıklı kimlik ayrışımını engeller. Oldukça az yaşanan birlik-beraberlik duygusu ise, her bir üyenin bağımsız ve özerk harekete sahip, birbirlerine bağl1lık hissetmeyen aile üyeleri haline dönüşebileceği duygusunu ifade etmektedir (Ümmet, 2007). Tüm 
dünyayı derinden etkileyen ve bazı olgularda ölümcül olabilen bir salgından ruhsal açıdan etkilenmek "normal" bir durumdur (Ercan vd., 2020).

Covid-19 salgını hızla yayılmaya devam ederken, yaşam tarzımızda oluşmaya başlayan değişiklikler de gözle görülür bir hal almaya başlamıştır. Ailede kriz dönemi olarak tanımlayabileceğimiz bu dönem mücadele gerektiren bazı büyük sorunlar ya da üstesinden gelinen güçlükler/sıkıntılar; ailenin yüksek kalitede evlilik iletişimini, yaşam kalitesinden tatmin olmasını, finansal yönetim becerisini, farklı koşullara dayanıklılı̆̆ını, rutin faaliyetlerini ve geleneklerini etkilemektedir. Özellikle ailelerin bu süreçte aşırı kaygılı, korkutucu, aşırı titiz, koruyucu-kollayıcı yaklaşımları olabilmektedir. Anne babaların abartılı panik hissi, çocukların ve gençlerin ruh sağlığını olumsuz etkileyebilir. Bu koşullarda stres altında olma daha fazla saldırganlığa, anlaşmazlıkların kolayca yükselebilmesine ve çatışmaya yol açabilmektedir. Bu durumdan en fazla, daha az (maddi ve maddi olmayan) kaynağa sahip ailelerin etkilendiği bilinmektedir. Salgın öncesi mali sıkıntı veya iliş̧i sorunları yaşayan ailelerde çatışma durumunu etkileyen önemli faktörler olduğu düşünülmektedir (Kluwer, 2020).

Hocker ve Wilmot (1995) çatışmayı bir tarafın ulaşmaya çalıştı̆̆ amaçlara başka bir tarafın müdahale ettiği, kıt kaynakları ve birbiriyle uyuşmayan amaçları olan en az iki taraf arasındaki mücadele olarak tanımlanmaktadır. Başka bir tanım ise şöyledir; birbiriyle ilişki içinde bulunan iki ya da daha fazla taraf arasında, kaynakların sınırlı olması, değerlerin, gereksinimlerin ve çıkarlarının birbiriyle uyuşmaması sonucu ortaya çıkan anlaşmazlıktır (Akbalık, 2001: 8). Moos ve Moos (1981), aile çatışmasını spesifik fakat dar bir tanımda ele almışlardır. Çatışma, aile üyeleri arasında açıkça ifade edilen öfke, saldırganlık durumu olarak ifade edilmiştir. Beavers ve Hampson'ın (1990) tanımı ise, açık / gizli kavga, tartışma, suçlama, kişisel sorumluluğun kabulü ve ailede olumsuz durumunu da içermektedir.

Sonuç olarak; mevcut durumun istikrarsız bir aile sistemine yol açmasının engellenmesi büyük önem taşımaktadır. Aslında tüm dünyada aynı anda yaşanan bu olağan dışı durumda, bu tarz duyguların yaşanması, istenmeyen düşüncelerin akla gelmesi ve rutin davranışların değişmesi de şaşırtıcı değildir (Ercan vd., 2020).

Sağlığı tıbbi bir mesele olarak ele almanın yanı sıra sosyal, psikolojik, toplumsal ve bireysel boyutlarının da düşünülmesi salgın açısından hem kısa hem de uzun vadede başarılı olmak için gereklidir. Hakkında çok fazla bilgiye sahip olunmayan Covid-19'un literatürdeki önemi göz önüne alındığında, hanehalkı üyelerinin çatışma ve birlik/beraberlik durumları konusundaki verilerin ortaya konulmasının; birey, toplum ve devlet otoritelerine geçerli öneriler verilmesi ve uzun vadeli politikalar oluşturulması açıdan önemli olduğu düşünülmektedir. Bu kapsamda, bu çalışma, Covid19 salgınının etkisiyle hanehalkı üyelerinin ilişkilerinde ortaya çıkması muhtemel çatışma ve birlikberaberlik durumunu etkileyen faaliyetleri incelemek amacıyla planlanmış ve yürütülmüştür.

\section{Yöntem}

\section{Örneklem ve Veri Toplama Yöntemi}

Araştırmada veri toplama yöntemi olarak nicel araştırma yöntemi, veri toplama aracı olarak da online anket seçilmiştir. Çalışmada çevrimiçi veri toplama yönteminin seçilmesinin nedeni, yöntemin daha kısa zamanda sonuç alınabilmeye ve deneklerin veri toplama aracını kendilerine en uygun zaman diliminde doldurabilmesine imkân sağlamasıdır (Ural ve Kılıç, 2011, s.62). Ayrıca online veri toplama yöntemi belirli özelliklere sahip gruplara ulaşımın kolay olmasına, zaman ve kağıt tasarrufu sağlamasına da neden olmaktadır.

Çalışmamız için, Hacettepe Üniversitesi Etik Kurulunun 23 Haziran 2020 tarihli toplantısında 35853172-200 sayılı etik kurul onayı alınmıştır. "Google Forms" aracılığıyla hazırlanan "Covid-19 Pandemi Döneminde Hanehalkındaki Çatışma ve Birlik-Beraberlik Durumunun İncelenmesi” anketi online olarak 23 Haziran- 10 Temmuz 2020 tarihleri arasında 18 
yaş üzerindeki hanehalkı üyelerine uygulanmıştır. Çalışma grubundaki çeşitliliği artırmak amacıyla "Google Forms" çevrimiçi ortamına aktarılan görüşme formu, farklı yaş ve cinsiyetteki hanehalkı üyelerine sosyal ağ (WhatsApp, Facebook) uygulamaları üzerinden ulaştırılmıştır. Araştırma formunun uygulama aşamasına geçilmeden önce araştırma formunun ilk sayfasında; araştırmanın amacı, araştırmaya katılımın araştırmacı için önemi, verilen cevapların gizliliği, katılımın tamamıyla gönüllü olduğu ve araştırmacıyla irtibat hakkında katılımcılara ön bilgi verilmiştir.

Online anket yapılması ile Türkiye'nin birçok farklı şehrinde yaşayan hanehalkına ulaşmak kolaylaşmış ve araştırmaya Türkiye'nin farklı illerinden (46 il) toplamda 372 hanehalkı üyesi katılmıştır.

Örneklem oluşturulurken, istatistik bilimine dair ve akademik çevrelerde yaygın olarak kabul edilen aşağıdaki kriterler dikkate alınmıştır. (Altunışık vd. 2005). Herhangi bir araştırmada 30'dan büyük 500'den küçük örneklem büyüklükleri birçok araştırma için yeterli olmaktadır. Çok değiş̧kenli analizlerin birçoğu için (Altunışık vd. 2017:143-144) genel bir kural olarak denek sayısının ölçekteki madde sayının en az 5 katı olması gerektiği; ya da denek sayısının ölçekteki madde sayının 10 katı olmasının daha kabul edilebilir bir oran olduğunu vurgulanmaktadır (Hair vd., 1998). Bu araştırmada kullanılan ölçekte toplam 30 madde bulunmakta ve madde sayısının 10 katı ölçütünü sağladığı için 372 kişilik örneklem grubu yeterli görülmektedir.

\section{Veri Toplama Araçları}

$\mathrm{Bu}$ araştırmada hanehaklı çevresindeki Covid-19'un etkisini belirlemek amacıyla Chaves ve Gattamorta (2020) tarafından geliştirilen Covid-19 Hanehalkı Çevre Ölçeği (CHÇÖ) (Covid-19 Household Environment Scale (CHES) kullanılmıştır. CHÇÖ ailenin işleyişinin, aile içi çatışmanın ve birlik/beraberliğin boyutlarını ölçmek için geliştirilmiştir.

Orijinali İngilizce olan ölçeğin dil geçerliliği çalışması, uzman akademisyenler tarafından yapılan çeviriler bir araya getirilmiş ve her bir maddeyi en iyi temsil ettiği düşünülen ifadeler cümle haline getirilmiştir. Oluşturulan Türkçe form, İngilizceye tekrar çevrilerek ölçeğin orijinal hali ile arasındaki farklar akademisyenlere inceletilmiştir. Sonuç olarak da Türk kültürel özellikleri dikkate alınarak değerlendirilen formların eşdeğer olduğu belirlenmiştir.

$\mathrm{Bu}$ çalışmada, CHÇÖ’nin güvenirliği, iç tutarlık (Cronbach's Alpha) katsayısı ile hesaplanmıştır. Ölçeğin Cronbach's Alpha katsayısı çatışma alt boyutu için $(0,89)$, birlik ve beraberlik alt boyutu için $(0,91)$ ve ölçeğin toplamı için ise $(0.92)$ olarak ölçülmüştür. Ölçeğin güvenirlik sonuçları oldukça yüksek düzeydedir.

Covid-19 Hanehalkı Çevre Ölçeği (CHÇÖ) 2 bölümden oluşmaktadır. Birinci bölümünde katılımcıların demografik özelliklerini, hane halkı kompozisyonunu (hane halkına ilişkin bilgiler) ve hane halkı düzeyinde Covid-19 pandemi döneminde sağlık ve çalışma yaşamına ilişkin karşılaşılan sorunları belirlemeye yönelik sorular yer almaktadır. İkinci bölümde ise Covid-19 pandemi dönemi ve öncesindeki hanehalkı düzeyinde çatışma ve birlik/beraberlik durumunu belirleyici çeşitli faaliyetler yer almaktadır. Ölçek her biri 15 maddeden oluşan 2 alt boyuttan (Hanehalkı çatışma durumu ve hanehalkı birlik ve beraberlik durumu) oluşmaktadır. Maddeler 5 puanlı bir ölçek üzerine derecelendirilmiştir. (Öncesiyle aynı: 1, Öncesinden çok daha az:2, Öncekinden biraz daha az: 3, Öncesinden biraz daha fazla:4, Öncesinden çok daha fazla:5) Her iki alt boyut içinde (Hanehalkı çatışma durumu ve Hanehalkı birlik ve beraberlik durumu) katılımcılar en az 15, en fazla 75 puan alabilirler. Hane halkı çatışması için puanlar arttıkça hanehalkı çatışma düzeyi artmaktadır. Aynı şekilde hanehalkı birlik ve beraberlik için puan arttıkça birlik ve beraberlik düzeyi artmaktadır.

\section{Verilerin Analizi}

Araştırmada elde edilen veriler IBM SPSS Statistics 20 paket programı aracılığıyla analiz edilmiştir. Sonucun güvenilir olup olmadığına Cronbach's Alpha $(\alpha)$ değerine bakılarak karar 
verilmiştir. Verilerin analizi için ise frekans, yüzdelik, ortalama, standart sapma, tek yönlü anova ve bağımsız örnekler t testi tekniği kullanılmıştır.

\section{Bulgular ve Tartışma}

Araştırma kapsamına alınan hanehalkı üyelerinin \% 62,6'sının kadın, \%35,8'inin 25-34 yaş grubunda, \%52,4'ünün üniversite mezunu, \%57,0'1nın ise bekar oldukları bulunmuştur. Gelir düzeyini orta olarak algılayanların oranı $(\% 74,5)$ en yüksektir (Tablo 1).

Tablo 1: Hanehalkı Bireylerinin Sosyo-Demografik Değişkenlere Göre Dağılımları

\begin{tabular}{llll}
\hline & & $\mathbf{N}$ & $\mathbf{\%}$ \\
\hline Cinsiyet & Erkek & 139 & 37.4 \\
& Kadın & 233 & 62.6 \\
\hline Yaş Grubu & $18-24$ & 125 & 33.6 \\
& $25-34$ & 133 & 35.8 \\
& $35-44$ & 65 & 17.5 \\
& 45 ve üstü & 48 & 12.9 \\
\hline Eğitim Durumu & İlkokul mezunu ve daha az & 11 & 3.0 \\
& Lise mezunu & 104 & 28.0 \\
& Üniversite mezunu & 195 & 52.4 \\
& Yüksek lisans mezunu & 40 & 10.8 \\
& Doktora mezunu & 22 & 5.9 \\
\hline Algılanan gelir düzeyi & Düşük & 48 & 12.9 \\
& Orta & 277 & 74.5 \\
& Yüksek & 47 & 12.6 \\
\hline Medeni durum & Bekar & 212 & 57.0 \\
& Evli & 145 & 39.0 \\
& Boşanmiş/Dul & 15 & 4.0 \\
\hline Toplam & & $\mathbf{3 7 2}$ & $\mathbf{1 0 0}$ \\
\hline
\end{tabular}

Bireylerin hanehalkı kompozisyonları incelendiğinde; evde 3-4 kişi yaşayanların oranı $\% 59,1$ olup, tamamına yakınının $(\% 93,5)$ hanesinde aile üyesi dışında kişi yaşamamaktadır. Evde yaşayan 65 yaş ve üstü yetişkin oranı \%12,9 dur. Çocuk sahibi olmayan hanehalkı üyesi $\% 66,4$, bunlar arasında 5 yaş ve altı çocuğa sahip olanların oranı \%13,7 dir. Hanede sağlık sorunları veya engellilik nedeniyle bakım gerektiren yetişkin (16) ve engelli veya özel sağlık ihtiyacı olan çocuk sayısı (11) oldukça azdır. Katılımcıların \%37,1'inin evinde 3 yatak odası bulunurken ev sahibi olanların oran $1 \% 71,5 \operatorname{dir}$ (Tablo 2). 
Tablo 2: Bireylerinin Hanehalkı Kompozisyonuna Göre Dağılımları

\begin{tabular}{llll}
\hline & & $\mathbf{N}$ & $\mathbf{\%}$ \\
\hline Evde yaşayan toplam kişi sayısı (N=372) & $1-2$ kişi & 85 & 22,9 \\
& $3-4$ kişi & 220 & 59,1 \\
& $5+$ kişi & 67 & 18,0 \\
\hline Evde yaşayan aile üyesi olmayan kişi & Var & 24 & 6,5 \\
& Yok & 348 & 93,5 \\
\hline Evde yaşayan 65 yaş ve üstü yetişkin & Var & 48 & 12,9 \\
& Yok & 324 & 87,1 \\
\hline Sağlık sorunları veya engellilik nedeniyle bakım gerektiren yetişkinlerin & Var & 16 & 4,3 \\
bulunma durumu(Covid-19 nedeniyle değil) & Yok & 356 & 95,7 \\
\hline Çocuk Sahibi Olma Durumu & Evet & 125 & 33,6 \\
& Hayır & 247 & 66,4 \\
\hline Çocuk sayısı N=162 & 5 yaş altı & 51 & 13,7 \\
& $5-11$ yaş & 34 & 9,2 \\
& $12-18$ yaş & 35 & 9,5 \\
& $18+$ & 42 & 11,3 \\
\hline Engelli veya özel sağlı ihtiyacı olan çocuk & Var & 11 & 3,0 \\
& Yok & 361 & 97,0 \\
\hline Evdeki yatak odası sayısı & 1 & 69 & 18,5 \\
& 2 & 126 & 33,9 \\
& 3 & 138 & 37,1 \\
& 4 ve üzeri & 39 & 10,5 \\
\hline Ev sahibi olma durumu & Evet & 266 & 71,5 \\
& Hayır & 106 & 28,5 \\
\hline Toplam & & $\mathbf{3 7 2}$ & $\mathbf{1 0 0}$ \\
\hline
\end{tabular}

Tablo 3'te görüldügüü üzere, araştırma kapsamına alınan hanehalkı üyelerinin \% $\%$ 75,0'inin 2 aydan fazla süredir sosyal mesafeyi koruma uygulamasını sürdürdüklerini, $\% 92,5$ 'inin sosyal mesafeyi koruduklarını belirtmişlerdir. T.C. Sağlık Bakanlığı öncülüğünde ülkemizin pandemi sürecini doğru yönettiği ve birçok kesiminin alınan önlemlerle de birlikte sosyal mesafeyi koruduğu görülmektedir. Sağlık bakanlığının hızla kurulan Bilim Kurulu ile koordineli çalışarak bu süreci soğukkanlı ve bilimsel kararlar ile yürüttüŭü söylenebilir. Eğitim kurumlarında eğitime ara verilmesi, 65 yaş üstü ve 18 yaş altı gruptaki bireylere uygulanan sokağa çıkma yasağ 1 ve sosyal mesafenin korunamaması riski taşıyan işletmelerin faaliyetlerinin geçici olarak durdurulması gibi önlemlerin, pandemi sürecinde sosyal mesafenin sağlanmasındaki başarıda rol oynadığı bu çalışmadan da anlaşılmaktadır.

Hanehalkının herhangi birinde Covid-19 belirtisi olanların sayıs1 13 olup bunlar arasından 2 kişiye test yapıldığ 1 , sonucunun da pozitif çıktı̆̆ 1 ve 1 kişinin hastaneye yatması gerektiği saptanmıştır. Ailesinde (evinizin içinde veya dışında) Covid-19 veya ilgili komplikasyonlardan dolayı vefat edenlerin sayısı 7 dir. Hanehalkı üyeleri arasında doğrudan hasta temaslı sağlık sektöründe çalışanların oranının \%10,2, Covid-19 bulaşma riskinin yüksek olduğu bir işte çalışanların oranının ise \%30,9 olduğu bulunmuştur. Hane halkı üyelerinin $\% 54,8$ 'i Covid- 19 pandemi döneminde evden çalışmakta olup bu dönemde işten ayrılmak zorunda kalanların oranı ise \%11,2 dir (Tablo 3). İşten ayrılanların oranına bakıldığında ise ekonomik kaynaklı yaşanabilecek sorunlar doğrultusunda hane halkında çatışmaların yaşanabilme ihtimalinin arttığ söylenebilir. Nitekim Mcloyd (1990) tarafindan finansal güçlüklerin aileler üzerindeki etkisinin incelemek amacıyla yapılan araştırma sonucunda da, düşük gelirli yetişkinlerin faturaları ödeyememe, işini kaybetme, sık sık taşınma ve para konusunda endişe duyma gibi yaşamın güçlüklerinden kaynaklı zihinsel sağlık problemleri ve stres yaşadıkları, finansal açıdan güçlükler yaşayan ebeveynlerin daha çabuk sinirlendikleri ve sorunlarla baş edebilme başarılarının daha düşük olduğu belirlenmiştir. 
Tablo 3: Hanehalkı Bireylerinin Sosyal Mesafe ve Covid-19 Bilgileri

\begin{tabular}{|c|c|c|c|}
\hline & & $\mathbf{N}$ & $\%$ \\
\hline \multirow[t]{4}{*}{ Sosyal mesafe uygulama süresi } & Bir haftadan az & 7 & 1,9 \\
\hline & $\begin{array}{l}\text { Bir haftadan bir } \\
\text { aya kadar }\end{array}$ & 7 & 1,9 \\
\hline & $\begin{array}{l}\text { Bir ila iki ay } \\
\text { arası }\end{array}$ & 79 & 21,2 \\
\hline & İki aydan fazla & 279 & 75,0 \\
\hline \multirow[t]{2}{*}{ Sosyal mesafeyi koruma durumu } & Evet & 344 & 92,5 \\
\hline & Hayır & 28 & 7,5 \\
\hline \multirow[t]{2}{*}{ Hanehalkının herhangi birinde Covid-19 belirtisi olma durumu } & Evet & 13 & 3,5 \\
\hline & Hayır & 359 & 96,5 \\
\hline \multirow[t]{2}{*}{ Evet ise test edildi mi (N:13) } & Evet & 2 & 15,4 \\
\hline & Hayır & 11 & 84,6 \\
\hline \multirow[t]{2}{*}{ Evet ise teşhis konulmuş bir vaka mıydı (pozitif sonuç) } & Evet & 2 & 15,4 \\
\hline & Hayır & 11 & 84,6 \\
\hline \multirow[t]{2}{*}{ Evet ise hastaneye yatmayı gerektirdi mi } & Evet & 1 & 7,7 \\
\hline & Hayır & 12 & 92,3 \\
\hline \multirow{2}{*}{$\begin{array}{l}\text { Ailenizdeki (evinizin içinde veya dışında) herhangi biri Covid-19 } \\
\text { veya ilgili komplikasyonlardan vefat etti mi? }\end{array}$} & Evet & 7 & 1,9 \\
\hline & Hayir & 365 & 98,1 \\
\hline \multirow{2}{*}{$\begin{array}{l}\text { Covid-19 salgını sırasında siz veya evde herhangi bir kişi doğrudan } \\
\text { hasta temasıyla sağlık sektöründe çalışıyor muydu? }\end{array}$} & Evet & 38 & 10,2 \\
\hline & Hayır & 334 & 89,8 \\
\hline \multirow{2}{*}{$\begin{array}{l}\text { Pandemi sırasında, siz veya evde herhangi bir kişi Covid-19 ile riski } \\
\text { yüksek olduğunu düşündüğünüz bir işte çalışıyor muydunuz? }\end{array}$} & Evet & 115 & 30,9 \\
\hline & Hayır & 257 & 69,1 \\
\hline \multirow[t]{2}{*}{ Evdeki yetişkinlerin evden çalışma durumu } & Hiç & 168 & 45,2 \\
\hline & 1 & 204 & 54,8 \\
\hline \multirow{4}{*}{$\begin{array}{l}\text { Evdeki yetişkinlerden kaç tanesi Covid-19 sonucu işten ayrılmak } \\
\text { zorunda kaldı? }\end{array}$} & Hiç & 330 & 88,8 \\
\hline & 1 & 34 & 9,1 \\
\hline & 2 & 6 & 1,6 \\
\hline & 3 ve üzeri & 2 & 0,5 \\
\hline Toplam & & 372 & 100 \\
\hline
\end{tabular}

Tablo 4'de CHÇÖ'nin ortalama, standart sapma, minumum ve maksimum değerleri ile ölçeğin Cronbach's Alpha iç tutarlılık katsayısı sonuçları verilmiştir. İki boyuttan oluşan ölçeğin Cronbach's Alpha iç tutarlılık analizine göre; 1.boyut $\alpha=.894$, 2. boyut $\alpha=.916$. İç tutarlık katsayıs1 hesaplamasında Cronbach's Alpha değerinin ölçme aracının güvenirliği için alt sınır değeri $\alpha=0.70$ olarak alınmaktadır. Cronbach's Alpha değerinin 0.70 ve üstü olması ise ölçme aracının güvenirliği için yeterli görülmekte olup bu değeri karşılayan ölçme aracının güvenilir olduğu kabul edilmektedir (Altunışık vd., 2007).

Özellikle ailelerin bu süreçte aşırı kaygıl1, korkutucu, aşırı titiz, koruyucu kollayıcı yaklaşımları olabilmektedir. Anne babaların abartılı panik hissi, çocukların ve gençlerin ruh sağlığını olumsuz etkileyebilir. Aslında tüm dünyada aynı anda yaşanan bu olağan dışı durumda, bu tarz duyguların yaşanması, istenmeyen düşüncelerin akla gelmesi ve rutin davranışların değişmesi de şaşırtıcı değildir (Ercan vd., 2020). Bu durumda ailede bazı konularda çatışmalar artabilmekte ya da krizlerin yaşanmadığı normal akış düzenine göre değişimler olabilirken bazı konularda ise birlik ve beraberlik durumlarında yaşanan dayanışma değişim gösterebilmektedir.

İște bu çalışmada da hanehalkı bireylerinin çatışma durumu düzeyleri ortalamalarına $(39,55 \pm 16,50)$ ve birlik ve beraberlik durumu düzeyleri ortalamalarına $(42,22 \pm 17,22)$ bakıldı̆̆ında 
hem çatışma hem de birlik/beraberlik durumlarının pandemi öncesine göre orta düzeyin biraz üstünde arttığı görülmektedir. Bu durumun birlikte geçirilen zamanın zorunlu bir şekilde artması ile ortaya çıktığı düşüncesi akla gelmektedir. Bu durumu destekler biçimde Atalay (1976:97) çaışmasında evde bulunmaya zorlanmanın ailelerin temel kuşak çatışma alanını oluşturduğunu belirtmektedir. Ancak hanehalkı çevresi boyutları arasındaki puan farkına bakıldığında ise, Covid19 pandemi döneminde hanehalkındaki birlik ve beraberlik durumunun çatışma durumuna göre daha yüksek olduğu görülmektedir (Tablo 4). Zira aile dışındakilerle olan sosyal mesafenin korunduğu ve manevi olarak zorlayıcı olan bu pandemi sürecinde aile içi birlik/beraberlik durumlarının çatışma durumuna göre artması beklenen bir sonuçtur. Buna ek olarak paylaşım sağlanan konu ve alanlardaki sürenin uzunluğunun artması ile pandemi öncesine göre birlik/beraberlik durumunun artmas1 da olağan bir bulgu olarak karşımıza çıkmaktadır.

Tablo 4: Ölçek ve Alt Boyutları İçin Tanımlayıcı İstatistikler ve Güvenilirlikler

\begin{tabular}{lccccc}
\hline & Ortalama & Standart Sapma & Minimum & Maksimum & Cronbach's Alfa \\
\hline Hanehalkı Çevresi Ölçeği & 81,78 & 28,83 & 0,00 & 150,00 & 0,925 \\
\hline Çatışma Durumu & 39,55 & 16,50 & 0,00 & 75,00 & 0,894 \\
\hline Birlik/ Beraberlik Durumu & 42,22 & 17,22 & 0,00 & 75,00 & 0,916 \\
\hline
\end{tabular}

\section{Hanehalkı Çatıșma Durumu}

Covid-19 döneminde hanehalkında yaşanan çatışma konu ve alanlarının önceki dönemlere göre değişme durumu incelendiğinde; kişisel temizlik/hijyen $(\% 58,6)$ ve sağlığın korunmas1 konularında (ör. ilaçları zamanında almak, doktora gitmek, yeterince yemek yemek) $(\% 54,0)$ önceki dönemlere göre çatışmanın daha fazla arttığı görülmektedir (Grafik 1). Kişisel temizlik/hijyen ve sağlığın korunması konularındaki çatışmaların önceki dönemlere göre artması Covid-19 sürecinde T.C. Sağlık Bakanlığı aracılığıyla yapılan kamu spotları, bilgilendirmeler ve daha birçok yolla toplumda bu konularda oluşturulan yüksek farkındalıktan ve zaman zaman oluşan bilgi kirliliğinden kaynaklandığı tahmin edilebilir. Ercan vd.'nin (2020) da belirttiği gibi, enfeksiyon hastalıkları, göğüs hastalıkları, mikrobiyoloji, halk sağlığı uzmanları ve ruh sağlığı çalışanları gibi konunun ehli kişilerin söyledikleri dışında basılı ve sosyal medyada yer alan spekülatif açıklamalara itibar edilmemesi gerekmektedir; buna ek olarak anne ve baba doğru bilgilenip kendisinin ve çocuklarının karşı karşıya olduğu riskleri ve yapması gerekenleri netleştirirse çocuklarına güven duygusunu aşılayabilecektir. Hiç kuşkusuz böylece bu ve benzer konularda bilgi kirliliğinden kaynaklanan çatışmaların önüne geçmek mümkün olabilecektir.

Çalışmada çatışmanın arttığı görülen diğer konular ise ev işleri (ör. evin temizlik veya düzeni, çamaşır yıkama, ütü vb) $(\% 56,2)$ ve yemek hazırlamadır (ör. Ne satın alınacak, hangi yiyecekler pişirilecek veya ne kadar yenecek $)(\% 54,3)$. Covid-19 sürecinde yaşanan sosyal izolasyon ile birlikte hanehalkının zamanının çoğunu evde geçirmesi dolayısıyla en temel ev faaliyetleri olan ev işleri ve yemek hazırlama gibi konularda hanehalkı arasında çatışmalar çıkması ise beklenen bir durum olarak karşımıza çıkmaktadır.

Covid-19 pandemi döneminde ebeveynlik ve hanehalkı sorumluluklarıyla ilgili sosyal normlar açısından, kadınlar birden fazla rolü yönetmek ve / veya dengelemek için ek zorlanma yaşıyor olabilirler. Özellikle kadınların bu dönemde sürekli yemek yapmak, ev temizlemek, çocukların bakımını üstlenmek gibi çoklu rol çatışması veya iş ve aile gibi çoklu yaşam rollerinin çatışması olarak hanehalkına yansımış görünmektedir. Nitekim rol çatışmasının gerginlik ve refahla karş1lıklı olarak ilişkili olduğunu bulmuştur (Nohe vd., 2015).

Covid-19 Döneminde mahremiyetin korunması (\%36,3), ebeveynlik veya çocuk bakımı, $(\% 33,6)$ ve siyaset ve politika $(\% 32,0)$ konularında önceki dönemlere göre çatışma durumunda bir farklılık yaratmadığı belirlenmiştir (Grafik 1). 
Covid-19 Döneminde evden dişarı çıkma (ör. iş, randevu, ziyaretler) $(\% 34,6)$, eve gelen misafirler $(\% 31,2)$, alkol, tütün veya uyuşturucu kullanımı $(\% 23,7)$ ve boş zamanları değerlendirme (ör. TV izlemek, hobiler, oyunlar, egzersiz yapma) $(\% 20,5)$ önceki dönemlere göre daha az çatışma yaşanılan faaliyetleri oluşturmaktadır (Grafik 1). Sosyal izolasyonla birlikte evin dışında yapılan faaliyetlerin azalmasıyla aile fertleri aileyle vakit geçirmeye daha istekli olabilirler (De Vos, J., 2020). Bu doğrultuda özellikle aile odağında gerçekleşen sosyalleşme faaliyetlerinde yaşanan çatışmaların azalması ilgi çekici bir sonuç olarak karşımıza çıkmaktadır.

Grafik 1: Covid-19 Döneminde Hane halkında Yaşanan Çatışma Konu ve Alanlarının Önceki Dönemlere Göre Değişme Durumu

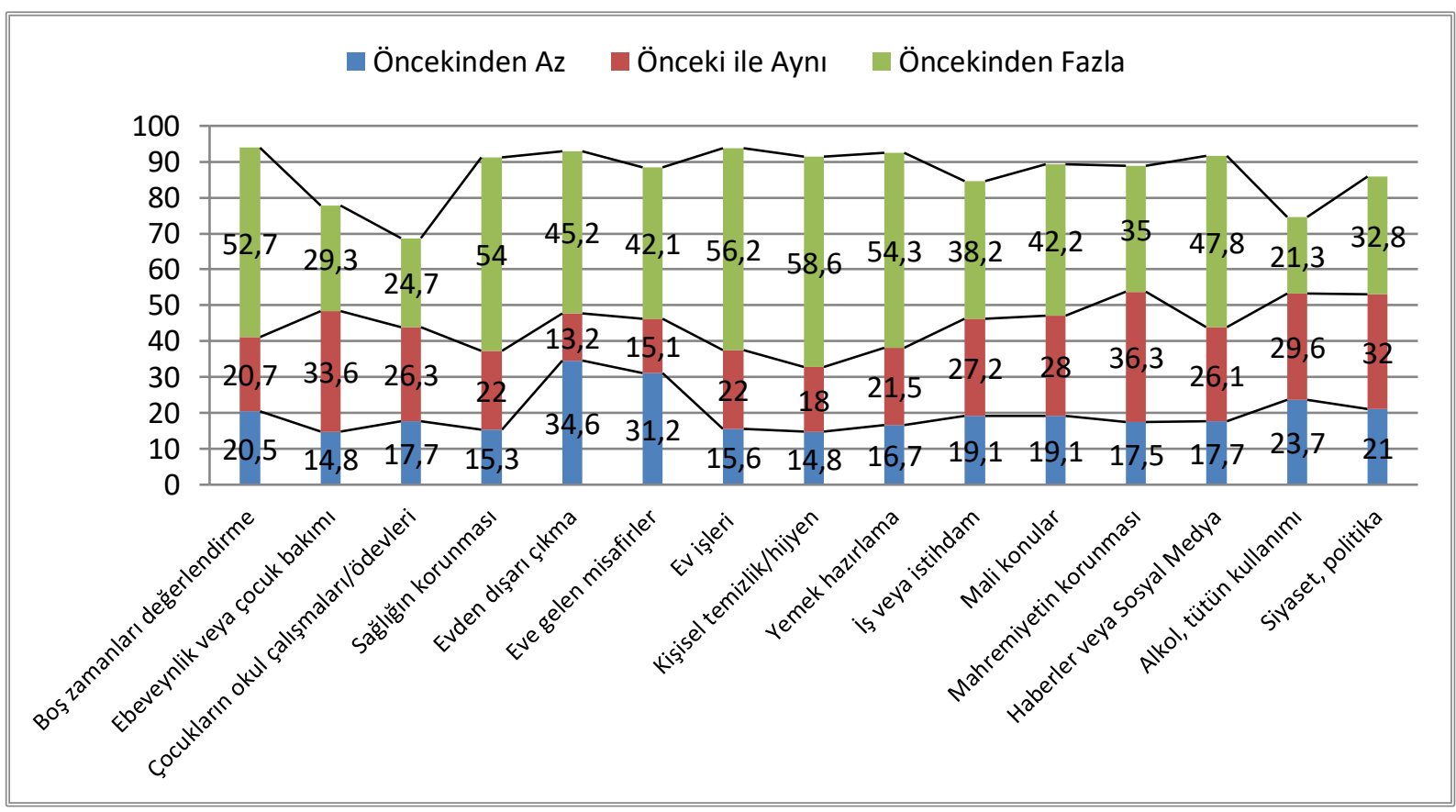

\section{Hanehalkı Birlik ve Beraberlik Durumu}

Ailenin birlikte geçirdiği zaman ve ilişkilerini gösteren davranışlar Covid-19 sürecindeki sosyal izolasyon gibi güçlüklere karşın aileye güvenin sürdürülmesinde olumlu etkiye sahiptir. Bu davranışlar aile yemeklerini, ailenin birlikte oyun oynadıkları geceleri, aile gezilerini, aile toplantılarını ve aile geleneklerini içerebilir. Destekleyici ilişkiler, aile üyelerinin yeteneklerinin geliştirilmesine, öğrenilmesine ve birbirleriyle olan ilişkilerinin güçlendirilmesine yardımcı olabilir (Simon, Murphy ve Smith, 2005). Sosyal mesafeli tedbirlerin hanehalk1 faaliyetlerine katılim üzerinde önemli etkileri olmuştur. Bu çalışmada da Covid-19 döneminde hanehalkı üyelerinin birlik ve beraberlik içinde olmalarına katkı sağlayan aktivitelerin önceki döneme göre değişme durumu incelendiğinde; boş zamanları birlikte geçirme (ör. hobiler, televizyon izleme, oyun oynamak, sosyal medya) (\%61,3), ev işlerini paylaşma (ör. Yemek pişirme, bahçe işleri, çamaşır yıkama, temizlik) $(\% 60,7)$, birbirlerine yardım etme (ör. teknoloji kullanımı ile sağlı ihtiyaçları ile) $(\% 60,2)$ ve sohbete katılma $(60,0)$ faaliyetlerinin önceki döneme göre daha fazla arttığ 1 görülmektedir (Grafik 2). Sosyal izolasyon sürecinde hanehalkının bir arada geçirdiği zamanın artmasıyla birlikte hanehalkı arasındaki paylaşımların da bu doğrultuda arttığı görülmektedir.

Covid-19 döneminde birlik ve beraberliğe katkı sağlayan kaynakları paylaşma (ör. kişisel eşyalar, kitaplar, para) $(\% 36,3)$, dini ve manevi faaliyetleri paylaşma (ör. dua etmek, meditasyon 
yapmak, dini konuşmalar) $(\% 35,8)$ ve eş/partnerle olan fiziksel yakınlığın $(\% 33,6)$ önceki dönemlere göre değişiklik göstermediği bulunmuştur (Grafik 2).

Covid-19 döneminde hanehalkı üyelerinin birlik ve beraberlik içinde olmalarına katk1 sağlayan sevgi/şefkat gösterme (sarılma, kucaklaşma, öpme) $(\% 23,7)$, eş/partnerle olan fiziksel yakınlık $(\% 22,4)$, birlikte egzersiz ve spor yapma (\% 17,7) ve ev dışı işleri birlikte yapma (ör. pazara veya eczaneye gitmek) $(\% 16,2)$ aktivitelerde önceki dönemlere göre azalma olduğu saptanmıştır (Grafik 2). Hanehalkı üyelerinin Covid-19 bulaşma riskini en aza indirmek için kişisel ve fiziksel temas konusunda birlik ve beraberlik içinde oldukları ve bu konuya önem verdikleri görülmektedir.

Grafik 2: Covid-19 Döneminde Hanehalkında Birlik ve Beraberliğe Katkı Sağlayan Aktivitelerin Önceki Dönemlere Göre Değişme Durumu

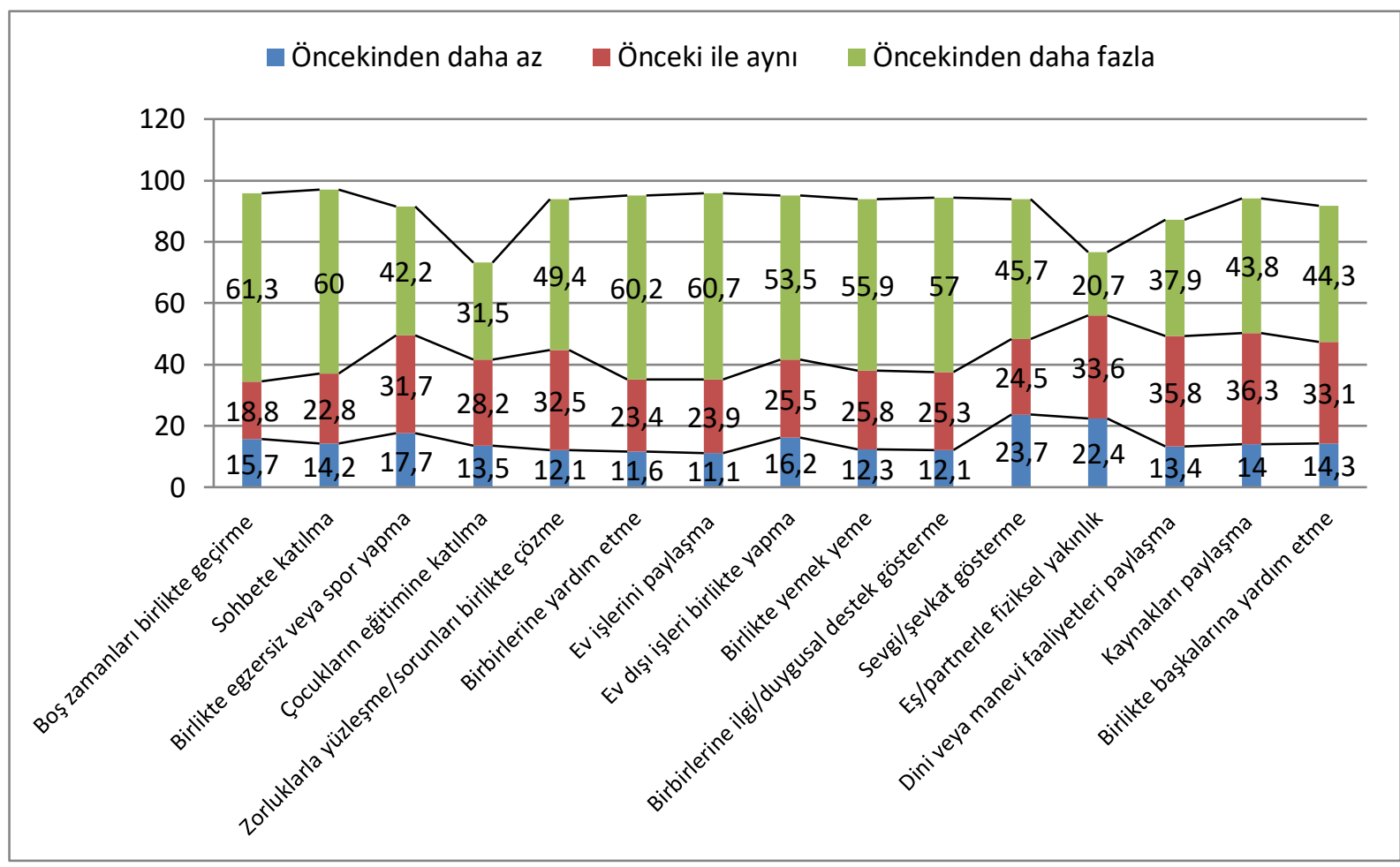

Tablo 5'de görüldüğü gibi; hanehalkı üyelerinin demografik değişkenler ve hanehalkı kompozisyonuna göre Covid-19 Döneminde Hanehalkı Bireylerin Çatışma Durumuna ilişkin Anova testi karşılaştırmasını gösteren dağılım incelendiğinde; katılımcıların yaş grupları, medeni durum, evde yaşayan çocuk durumu ve evde yaşayan toplam kişi sayısı ile çatışma durumu arasında anlamlı bir farklılık bulunduğu; cinsiyet, algılanan gelir düzeyi, evde engelli veya özel sağlık ihtiyacı olan çocuk ve $65+$ yaş grubunda bireyin bulunma durumu arasında çatışmaya yönelik ölçek puanı açısından istatistiksel olarak anlamlı fark bulunmadığı sonucuna ulaşılmıştır.

18-24 yaş grubunda olan hanehalkı üyelerinin Covid-19 döneminde çatışma durumuna ilişkin ortalamaları $44.95 \pm 15.28$ iken hanehalkı üyelerinin yaşları arttıkça çatışma durumu azalmaktadır (Tablo 5). Yaşı ilerlemiş hanehalkı bireylerinin yıllar içinde kazandıkları sorumluluk bilinci ve hayat tecrübesi ile yaşanan zorlı Covid-19 pandemi sürecinde hanehalkında yaşanabilecek çatışma konularında çok daha sakin ve bilinçli kaldıkları tahmin edilebilir. 
Bekar olan hanehalkı üyelerinin evli ve dul/boşanmış aile üyelerine göre çatışma durumunun arttı̆̆ görülmektedir (Tablo 5). Covid-19 döneminde hanehalkında çocuk üye bulunmayan ailelerde çatışma durumu ( $\mathrm{M} \pm \mathrm{SD}: 41.41 \pm 15.09)$ çocuk üye bulunan ailelere göre daha yüksektir (Tablo 5).

Tablo 5'te görüldüğü üzere bu çalışmada evde yaşayan kişi sayısı 5 ve üzeri olan hanehalklarında çatışma durumunun ( $\mathrm{M} \pm \mathrm{SD}$ : 44.48 \pm 14.81 ) 1-2 ve 3-4 kişi olan hanehalklarına göre daha yüksek olduğu görülmektedir. Yani evde yaşayan kişi sayısı arttıkça çatışma durumu artmaktadır. Benzer şekilde Miller ve Tucker (1993) hanehalkının sosyo-demografik özellikleri ile birlik ve beraberlik durumunu incelediği çalışmada; ailede yaşayan kişi sayısı ile hanehalkı birlik ve beraber durumu arasında istatistiksel olarak anlamlı fark olduğunu ve 4 kişiden büyük ailelerin aile ilişkilerinden bağımsız olduğunu bulmuşlardır.

Hanehalkı üyelerinin demografik değişkenler ve hanehalkı kompozisyonuna göre Covid-19 döneminde bireylerin birlik ve beraberlik durumuna ilişkin Anova testi karşılaştırmasını gösteren dağılıma göre; katılımcıların sadece algılanan gelir düzeyi ile birlik ve beraberlik puanlarında anlamlı bir farklılık bulunmaktadır. Miller ve Tucker (1993) tarafından yapılan çalışmada ise yüksek gelir düzeyine sahip ailelerin birbirleri ile çok daha fazla iletişim halinde oldukları, gelir açısından zorluk yaşayan ailelerin ise iletişimlerinin düşük seviyelerde kaldığ 1 görülmüştür. Bu çalışmada da, Tablo 5'te görüldüğü üzere hanehalkı üyelerinin algıladıkları gelir düzeyi arttıkça ailedeki birlik ve beraberlik durumu da artmaktadır. Covid-19 döneminde yüksek gelir algısı olan aile üyelerinin ailede birlik ve beraberlik içinde olma durumu ( $\mathrm{M} \pm \mathrm{SD}$ : 48.63 \pm 16.29$)$ orta $(\mathrm{M} \pm \mathrm{SD}: 43.03 \pm 15.90)$ ve düşük $(\mathrm{M} \pm \mathrm{SD}: 37.54 \pm 17.37)$ gelir algısında olan aile üyelerine göre daha yüksektir (Tablo 5).

Diğer demografik değişkenler ve hanehalkı kompozisyonu ile birlik ve beraberlik puanlarında anlamlı fark bulunmamıştır (Tablo 5). 
Tablo 5: Covid-19 Döneminde Hanehalkı Bireylerin Çatışma ve Birlik/Beraberlik Durumu ile Demografik Değişkenler, Hanehalkı Kompozisyonları ile Arasındaki İlişki (Anova Testi)

\begin{tabular}{|c|c|c|c|c|c|c|}
\hline \multirow[b]{2}{*}{ 1.Cinsiyet } & \multicolumn{3}{|c|}{ Çatışma Durumu } & \multicolumn{3}{|c|}{ Birlik/Beraberlik Durumu } \\
\hline & $M \pm S D$ & $p$ & Fark & $M \pm S D$ & $p$ & Fark \\
\hline Kadin & $38.87 \pm 16.44$ & \multirow{2}{*}{0.300} & \multirow{2}{*}{-} & $41.84 \pm 16.46$ & \multirow{2}{*}{0.578} & \multirow{2}{*}{-} \\
\hline Erkek & $40.70 \pm 16.58$ & & & $42.87 \pm 18.46$ & & \\
\hline 2.Yaş Grubu & $M \pm S D$ & $p$ & Fark & $M \pm S D$ & $p$ & Fark \\
\hline $18-24$ & $44.95 \pm 15.28$ & \multirow{4}{*}{$0.000 *$} & \multirow{4}{*}{$\begin{array}{l}1- \\
2.3 .4\end{array}$} & $42.15 \pm 16.48$ & \multirow{4}{*}{0.250} & \multirow{4}{*}{-} \\
\hline $25-34$ & $38.11 \pm 15.76$ & & & $41.27 \pm 16.98$ & & \\
\hline $35-44$ & $36.06 \pm 16.96$ & & & $45.92 \pm 17.85$ & & \\
\hline $45+$ & $34.66 \pm 17.53$ & & & $40.92 \pm 18.80$ & & \\
\hline 3.Medeni Durum & $M \pm S D$ & $p$ & Fark & $M \pm S D$ & $p$ & Fark \\
\hline Evli & $36.77 \pm 16.39$ & \multirow{3}{*}{$0.000 *$} & \multirow{3}{*}{$1-2.3$} & $43.08 \pm 16.96$ & \multirow{3}{*}{0.451} & \multirow{3}{*}{-} \\
\hline Bekar & $42.49 \pm 15.79$ & & & $41.37 \pm 17.53$ & & \\
\hline Boşanmış/dul & $25.00 \pm 15.95$ & & & $46.00 \pm 15.32$ & & \\
\hline 4. Algılanan Gelir & $M \pm S D$ & $p$ & Fark & $M \pm S D$ & $p$ & Fark \\
\hline Düşük & $42.72 \pm 16.66$ & \multirow{3}{*}{0.174} & \multirow{3}{*}{-} & $37.54 \pm 17.37$ & \multirow{3}{*}{$0.004 *$} & \multirow{3}{*}{$\begin{array}{l}3- \\
1.2\end{array}$} \\
\hline Orta & $40.37 \pm 15.63$ & & & $43.03 \pm 15.90$ & & \\
\hline Yüksek & $36.72 \pm 16.33$ & & & $48.63 \pm 16.29$ & & \\
\hline 5.Evde yaşayan çocuk durumu & $M \pm S D$ & $p$ & Fark & $M \pm S D$ & $p$ & Fark \\
\hline Var & $37.91 \pm 17.22$ & \multirow{2}{*}{$0.048 *$} & \multirow{2}{*}{-} & $43.68 \pm 16.64$ & \multirow{2}{*}{0.571} & \multirow{2}{*}{-} \\
\hline Yok & $41.41 \pm 15.09$ & & & $42.64 \pm 16.23$ & & \\
\hline $\begin{array}{l}\text { 6. Evde yaşayan engelli ve özel ihtiyact } \\
\text { olan çocuk }\end{array}$ & $M \pm S D$ & $p$ & Fark & $M \pm S D$ & $p$ & Fark \\
\hline Var & $43.54 \pm 18.18$ & \multirow{2}{*}{0.416} & \multirow{2}{*}{-} & $41.09 \pm 17.49$ & \multirow{2}{*}{0.831} & \multirow{2}{*}{-} \\
\hline Yok & $39.43 \pm 16.45$ & & & $42.26 \pm 17.23$ & & \\
\hline 7. Evde yaşayan 65+ yaş durumu & $M \pm S D$ & $p$ & Fark & $M \pm S D$ & $p$ & Fark \\
\hline Var & $36.97 \pm 14.63$ & \multirow{2}{*}{0.247} & \multirow{2}{*}{ - } & $42.47 \pm 15.46$ & \multirow{2}{*}{0.913} & \multirow{2}{*}{ - } \\
\hline Yok & $39.93 \pm 16.74$ & & & $42.18 \pm 17.49$ & & \\
\hline 8. Evde yaşayan toplam kişi sayısı & $M \pm S D$ & $p$ & Fark & $M \pm S D$ & $p$ & Fark \\
\hline 1-2 kişi & $37.79 \pm 16.10$ & & & $40.24 \pm 16.77$ & & \\
\hline 3-4 kişi & $38.84 \pm 16.96$ & $0.027 *$ & $\begin{array}{l}1-3 \\
2-3\end{array}$ & $42.25 \pm 17.43$ & 0.372 & - \\
\hline 5 ve üzeri & $44.48 \pm 14.81$ & & & $44.24 \pm 17.12$ & & \\
\hline
\end{tabular}

$*: \mathrm{p}<0.05$

Tablo 6'da görüldüğü gibi; hanehalk1 üyelerinin Covid-19 döneminde sağlık ve çalışma yaşamına ilişkin sorun yaşama durumlarına göre hanehalkı bireylerin çatışma durumuna ilişkin Anova testi karşılaştırmasını gösteren dağılım incelendiğinde; katılımcıların hanehalkı üyelerinin birinde Covid-19 belirtileri olma durumu ile hanehalkı üyelerinin sosyal mesafeyi koruma süresi ile çatışma durumu arasında anlamlı bir farklılık bulunduğu; diğer değişkenler arasında çatışmaya yönelik ölçek puanı açısından istatistiksel olarak anlamlı fark bulunmadığı sonucuna ulaşılmıştır.

Hanehalkı üyelerinden herhangi birinde Covid-19 belirtisi olan hanehalklarının çatışma durumu ortalama puanları $50.00 \pm 13.74$, belirti göstermeyen hanehalklarının ise $39.17 \pm 16.48$ dir Hanehalkı üyelerinin birinde Covid-19 belirtileri gösteren ailelerde çatışma durumunun, göstermeyenlere göre daha yüksek olduğu bulunmuştur (Tablo 6). Bu kayg1 verici ve stresli sürecin hanehalkında çatışmalara sebep olması olası bir durum olarak karşımıza çıkmaktadır. 
Covid-19 döneminde sosyal mesafeyi 1-2 ay arasında koruyan hane halk1 üyelerinin çatışmaya ilişkin puan ortalaması $42.45 \pm 14.23$ iken 2 aydan fazla süredir sosyal mesafeyi koruyan üyelerin puan ortalaması ise $38.59 \pm 17.10$ dir. Sosyal mesafeyi koruma süresi arttıkça çatışmanın azaldığ görülmektedir (Tablo 6). Sosyal mesafenin uzun süre devam etmesi sonucu hanehalk1 arasındaki iletişimin de benzer biçimde azalmasıyla çatışma konusu olacak durumların sayısının düşmesinin ve paylaşım süresinin de dolaylı biçimde kısalmasının buna sebebiyet verdiği düşünülebilir.

Hanehalkı üyelerinin Covid-19 döneminde sağlık ve çalışma yaşamına ilişkin sorun yaşama durumlarına göre hanehalkı bireylerin birlik ve beraberlik durumuna ilişkin olarak evde herhangi birinde Covid-19 belirtileri olanların, Covid-19 riski yüksek olan bir işte çalışanların, bu dönemde evden çalışanların, sağlık sektöründe çalışmayanların, Covid-19 nedeni ile vefat eden yakınlarının bulunanların hanehalkı içinde birlik ve beraberlik içinde olma puan ortalamalarının yüksek olduğu Tablo 6'da görülmektedir. Ancak belirtilen değişkenler ile birlik ve beraberlik içinde bulunma durumu arasında istatistiksel açıdan anlamlı bir farklılık bulunmamıştır (Tablo 6).

Tablo 6: Covid-19 Pandemi Döneminde Bireylerin Çatışma ve Birlik/Beraberlik Durumu ile Bu Dönemde Sağlık ve Çalışma Yaşamına İlişkin Sorun Yaşama Durumları Arasındaki İlişki (Anova Testi)

\begin{tabular}{|c|c|c|c|c|c|c|}
\hline \multirow[b]{2}{*}{$\begin{array}{l}\text { 1. Evde herhangi birinde Covid-19 } \\
\text { belirtileri olma durumu }\end{array}$} & \multicolumn{3}{|c|}{ Çatışma Durumu } & \multicolumn{3}{|c|}{ Birlik/Beraberlik Durumu } \\
\hline & $M \pm S D$ & $p$ & Fark & $M \pm S D$ & $p$ & Fark \\
\hline Var & $50.00 \pm 13.74$ & \multirow{2}{*}{$0.016 *$} & & $48.53 \pm 13.32$ & \multirow{2}{*}{0.108} & \\
\hline Yok & $39.17 \pm 16.48$ & & & $41.99 \pm 17.32$ & & \\
\hline $\begin{array}{l}\text { 2. Covid-19 riski yüksek olan bir işte } \\
\text { çalıșma durumu }\end{array}$ & $M \pm S D$ & $p$ & Fark & $M \pm S D$ & $p$ & Fark \\
\hline Evet & $40.57 \pm 16.15$ & \multirow{2}{*}{0.427} & \multirow{2}{*}{ - } & $41.99 \pm 17.16$ & \multirow{2}{*}{0.861} & \multirow[b]{2}{*}{ - } \\
\hline Hayır & $39.10 \pm 16.66$ & & & $42.33 \pm 17.28$ & & \\
\hline $\begin{array}{l}\text { 3. Covid-19 pandemisi sirasında evden } \\
\text { çalıșma durumu }\end{array}$ & $M \pm S D$ & $p$ & Fark & $M \pm S D$ & $p$ & Fark \\
\hline Var & $39.57 \pm 15.85$ & \multirow{2}{*}{0.982} & \multirow{2}{*}{-} & $43.75 \pm 16.13$ & \multirow{2}{*}{0.060} & \multirow{2}{*}{-} \\
\hline Yok & $39.53 \pm 17.29$ & & & $40.37 \pm 18.33$ & & \\
\hline $\begin{array}{l}\text { 4. Evde herhangi bir kişinin sağllk } \\
\text { sektöründe çalış̧a durumu }\end{array}$ & $M \pm S D$ & $p$ & Fark & $M \pm S D$ & $p$ & Fark \\
\hline Evet & $37.31 \pm 16.74$ & \multirow{2}{*}{0.378} & \multirow{2}{*}{-} & $40.76 \pm 16.77$ & \multirow{2}{*}{0.574} & \multirow{2}{*}{-} \\
\hline Hayır & $39.81 \pm 16.47$ & & & $42.39 \pm 17.29$ & & \\
\hline 5. Covid-19 vefat durumu & $M \pm S D$ & $p$ & Fark & $M \pm S D$ & $p$ & Fark \\
\hline Evet & $47.42 \pm 15.84$ & \multirow{2}{*}{0.203} & \multirow{2}{*}{ - } & $40.42 \pm 22.77$ & \multirow{2}{*}{0.781} & \multirow{2}{*}{-} \\
\hline Hayır & $39.40 \pm 16.49$ & & & $42.26 \pm 17.13$ & & \\
\hline 6. Sosyal mesafe koruma süresi & $M \pm S D$ & $p$ & Fark & $M \pm S D$ & $p$ & Fark \\
\hline Bir ila iki ay arası & $42.45 \pm 14.23$ & $0.033 *$ & & $42.56 \pm 15.91$ & 0.815 & \\
\hline İki aydan fazla & $38.59 \pm 17.10$ & & & $42.11 \pm 17.66$ & & \\
\hline
\end{tabular}
$*: p<0.05$

\section{Sonuç ve Öneriler}

Covid-19 salgınının etkisiyle hanehalkı üyelerinin ilişkilerinde ortaya çıkması muhtemel çatışma ve birlik-beraberlik durumunu etkileyen faaliyetleri incelemek amacıyla gerçekleştirilen 
araştırmada hanehalkı üyelerinin büyük çoğunluğunun 2 aydan fazla süredir sosyal mesafeyi koruma uygulamasını sürdürdükleri, tamamına yakınının ise şuanda sosyal mesafeyi korudukları görülmüştür.

Covid-19 bulaşma riskinin yüksek olduğu bir işte çalışanların oranının araştırmaya katılanların dörtte birinden biraz fazla olduğu; hanehalkı üyelerinin yarısından biraz fazlasının ise Covid-19 pandemi döneminde evden çalışmakta olduğu; çalışmaya katılan 10 kişiden birisinin ise işten ayrılmak zorunda kaldığı belirlenmiştir.

Çalışmada hanehalkı bireylerinin çatışma durumu ve birlik ve beraberlik durumu düzeyleri ortalamalarına bakıldığında hem çatışma hem de birlik/beraberlik durumlarının pandemi öncesine göre orta düzeyin biraz üstünde arttığı belirlenmiş ancak hanehalkı çevresi boyutları arasındaki puan farkına bakıldığında ise, Covid-19 pandemi döneminde hanehalkındaki birlik ve beraberlik durumunun çatışma durumuna göre daha yüksek olduğu görülmüştür.

Araştırma sonucunda Covid-19 döneminde kişisel temizlik/hijyen ve sağlığın korunması konularında (ör. ilaçları zamanında almak, doktora gitmek, yeterince yemek yemek) önceki dönemlere göre hanehalkı arasındaki çatışmanın yarı yarıya arttığı görülmüştür. Çalışmada çatışmanın arttığı görülen diğer konular ise ev işleri (ör. evin temizliği veya düzeni, çamaşır yıkama, ütü vb.) ve yemek hazırlama olarak karşımıza çıkmaktadır (ör. ne satın alınacak, hangi yiyecekler pişirilecek veya ne kadar yenecek?).

Çalışmada Covid-19 döneminde boş zamanları birlikte geçirme (ör. hobiler, televizyon izleme, oyun oynamak, sosyal medya), ev işlerini paylaşma (ör. Yemek pişirme, bahçe işleri, çamaşır yıkama, temizlik), birbirlerine yardım etme (ör. teknoloji kullanımı ile sağlık ihtiyaçları ile) ve sohbete katılma gibi birlik ve beraberliğe ilişkin faaliyetlerin önceki döneme göre daha fazla arttığı görülürken, sevgi/şefkat gösterme (sarılma, kucaklaşma, öpme), eş/partnerle olan fiziksel yakınlık, birlikte egzersiz ve spor yapma ve ev dışı işleri birlikte yapma (ör. pazara veya eczaneye gitmek) aktivitelerde ise önceki dönemlere göre azalma olduğu saptanmıştır.

Araştırmada hanehalkı üyelerinin birinde Covid-19 belirtileri olma durumu ile hanehalkı üyelerinin sosyal mesafeyi koruma süresi ile çatışma durumu arasında anlamlı farklılık bulunurken, hanehalk1 üyelerinin birinde Covid-19 belirtileri gösteren ailelerde çatışma durumunun göstermeyenlere göre daha yüksek olduğu görülmüştür.

Çalışmada sosyal mesafeyi koruma süresi arttıkça çatışmanın azaldığı görülmüştür. Covid19 döneminde sağlık ve çalışma yaşamına ilişkin sorun yaşama durumlarına göre ise evde herhangi birinde Covid-19 belirtileri olanların, Covid-19 riski yüksek olan bir işte çalışanların, bu dönemde evden çalışanların, sağlık sektöründe çalışmayanların, Covid-19 nedeni ile vefat eden yakınlarının bulunanların hanehalkı içinde birlik ve beraberlik içinde olma durumlarının yüksek olduğu saptanmiştır.

Bütün bu sonuçlar 1şı̆̆ında zorlu Covid-19 pandemi sürecinin ailelerde yaşattığ 1 sorunlar ortaya konmaktadır; bu doğrultuda hanehalkında yaşanan ve yaşanabilecek sorun ve çatışmaların çözümüne ilişkin oluşturulacak eğitim programları ve uygulamaları, akademik çalışmalar, projeler ve proje destekleri oldukça önemlidir.

Birçok ailede travmatik bir durum yaratan Covid-19 pandemi sürecinin atlatılması için yapılacak proje ve çalışmalar sivil ve devlet kurumları tarafından süreğen bir biçimde hanehalkında birlik ve beraberliğin artırılması yönünde desteklenmeli, yerel ve uluslararası düzeyde destekleyici fonlar ayrılmalı, bu konuda çalışan kurum ve kuruluşların sayısı arttırılmalıdır. Özellikle birlik ve beraberlik konusunda farkındalık sağlanması ile ortak değerler, inançlar, tutumlar ve kültürel yapıda sağlanacak birliktelik kuvvetlendirilecektir. 
$\mathrm{Bu}$ doğrultuda bütün yaş gruplarında verilecek eğitimler ile hayat boyu öğrenme yoluyla bu ve buna benzer kriz durumlarında hanehalkında birlik ve beraberliğin artırılması ve sürdürülmesi yönünde kurs programları oluşturulmalı ve yaygınlaştırılmalıdır. Bunun yanı sıra nesiller arası etkileşimi arttırmak için çeşitli yaş gruplarında entegrasyona yönelik uygulamalı eğitimler, rekreasyon faaliyetleri, okul organizasyonları ve projeler oluşturulmalı ve uygulanmalıdır.

Bütün bu öneriler doğrultusunda hanehalkında birlikteliğin geliştirilmesi bireylerin ve dolayısıyla ailelerin yaşam kalitelerinin yükseltilmesini ve aile birliğinin kuvvetlendirilmesini sağlayacaktır, bu yaklaşım ve politikalar toplumun refahına katkı sağlanması yönünde çok büyük önem arz etmektedir.

Bütün bu makro boyuttaki öneriler dışında hanehalkında yer alan bireylerin yaşadıkları çatışma durumlarını önlemek ve birlik beraberliği artırmak üzere şu öneriler sıralanabilir:

-Covid-19 pandemi süreci ve ailelerde yaşanabilecek benzeri kriz durumlarında ebeveynlerin kaygı ve panik halinde hareket etmeleri çocukların da benzer kaygı haline bürünmelerine sebep olabilmektedir; bu durumlarda ebeveynler kaygı durumlarını kontrol altına almalıdırlar ve yaşadıkları bu sıkıntılı ruh halini olabildiğince çocuklarından uzakta yaşamalıdırlar (Ercan vd., 2020). Böylesi durumlarda ebeveynler doğru bilgilenip kendilerinin ve çocuklarının karşı karşıya olduğu riskleri ve yapması gerekenleri netleştirirse çocuklarına güven duygusunu aşılayabilecektir.

-İletişim, hane halkı üyelerinin paylaştıkları duygulardan anlam çıkardıkları, strateji geliştirdikleri, uyum ve denge oluşturdukları önemli bir araçtır. Bu nedenle hanehalkı üyeleri yaşamdaki olaylara ve değişimlere karşın iletişim içinde olmalıdırlar. Aile içi iletişimi geliştirecek aktiviteler ile paylaşımları artırarak yaşanan ve yaşanabilecek hanehalkı çatışmaları en aza indirgemek mümkün olacaktır.

-Umut ve inanç, aileye stres durumlarında birliktelik, anlama ve üstesinden gelme yeteneği sağlayabilir. İnanç ve umudun paylaşılması hanehalkı üyelerinin oluşan bu değişimleri yorumlamalarına olanak sağlar.

-Özellikle Covid-19 döneminde esnek olma, süreklilik bilincini korurken, sıkıntılardan kurtulmak ve düzeni sağlamak üzere ailenin çaba gösterdiği önemli bir koruyucu ve iyileştirici faktördür. Kriz durumlarında aileler, uyumu ve dengeyi sağlamak için bazı durumlarda yaşam biçimini, anlamları, kuralları ve rolleri içeren fonksiyon modellerini değiştirmeye mecburdurlar. $\mathrm{Bu}$ durum aile üyelerinin birbirlerine bağlılığını da gösterir.

-Aile sistemini tehdit eden ya da değiştiren olaylar ve değişikliklerle karşı karşıya kalan ailelerde ümitsizlik ya da geleceğe ilişkin belirsizlikler görülmektedir. Ailenin uyum süreci ve direnci için umudunu koruma becerisi yaşamsal bir önem taşımaktadır.

-Pandemi dönemi gibi risk faktörleriyle karşılaşıldığında aile sisteminin sınırları zorlanır. Aile birlikte iş yapmak ve ortak güçlerini, amaçlarını ve doğruluk bilincini korumak için aile meclisini oluşturur. Aile sisteminin bu özelliği ailenin dayanıklılığ dayanıklılığı ailenin yaşadığı sıkıntıları tanımladığı, mevcut problemi belirlemek ve çözmek üzere paylaştığı sözleri içermektedir. Böylece aile kendisini sonuçlar üzerinde kontrol ve etki sahibi olarak görür. Ayrıca yakın ve geniş aile çevresi ile dengeli ilişkiler kurabilirlerse, ihtiyaçlarını dile getirerek ve birlikte zaman geçirerek zorluklarla mücadele etmede başarılı olabilirler.

-Aile yemekleri, günlük işler ve birlikte zaman geçirme gibi bir arada yapılan faaliyetler, aile yaşamında istikrarı ve devamlılığı sağlamada önemli bir role sahiptir. Örneğin; birlikte yemek yeme faaliyetinin ailenin birlikteliğini paylaşmada temel aktivite olduğu görülür. Bütün aile sistemleri uyum ve denge ortamını oluşturacak istikrarı ve beklentileri gerçekleştirmek amacıyla faaliyet ve davranış şekillerini geliştirmeye çalışır. Ailece yapılacak aktiviteler de ruh sağlığımızı korumak için 
çok yararlı olabilir. Hanehalkında birlik ve beraberliği artırmaya yönelik aktivitelerin çoğaltılması, hanehalkı üyelerinin bir arada kaliteli zaman geçirmesi için özenli programlar yapılmalıdır.

-Aile bütünlüğü ve sosyal destek sistemleri hoş ve koruyucu bir bağlllık ve ait olma duygusu yaratır. Bu duruma direnç gösteren aileler yaşadıkları toplumdan sosyal destek almakla kalmazlar aynı zamanda bu desteği topluma geri verirler.

-Sosyal iletişim ağı, başkalarının refahına katkıda bulunma yollarını, zamanı, bilgi ve hizmeti sağlamak üzere aileleri karşıllklı olarak etkileyebilir. Destek olma ve kaynak sağlama faaliyetleri stres oluşumunu engellemekte ve kendine güveni arttırmaktadır.

-Bu çalışmanın 1şık tutacağı umulan diğer çalışmaların daha büyük örneklemlerle farklı bölgelerde ve belirli periyodik zamanlarla tekrarlanması ise çalışmanın sonunda önerilmektedir.

\section{Kaynakça}

Akbalık, F. G. (2001). Çatışma çözme ölçeği'nin (üniversite öğrencileri formu) geçerlik ve güvenilirlik çalışması, Türk Psikolojik Danışma ve Rehberlik Dergisi 2 (16), 7-13.

Altunışık, R., Coşkun, R., Bayraktaroğlu, S. \& Yıldırım, E. (2005). Sosyal bilimlerde araştırma yöntemleri: SPSS uygulamalı. 4. bs.

Atalay, B. (1976), Köy Gençliği Üzerinde Sosyolojik Bir Araştırma.

Beavers, W. R., \& Hampson, R. B. (1990). Successful families: Assessment and intervention. W W Norton \& Co.

Behar-Zusman, V., Chavez, J.V. \& Gattamorta, K. (In Preparation), Developing a Measure of the Impact of Covid-19 Social Distancing on Household Conflict and Cohesion.

De Vos, J. (2020). The effect of Covid-19 and subsequent social distancing on travel behavior. Transportation Research Interdisciplinary Perspectives, 100-121.

Ercan, S. E.,, Arman A. R., Emiroğlu, İ. N. , Öztop, D. B., Yalçın, Ö. (2020). Türkiye Çocuk ve Genç Psikayatrisi Derneği Covid 19 (Korona) Virüs Salgını Arasında Aile, Çocuk ve Ergenlere Yönelik Psikososyal ve Ruhsal Destek Rehberi. https://www.ankara.edu.tr/Covid-19/ erişim tarihi 06.06.2020.

Ferguson, N. Cummings, D. Fraser, C. Cajka, J. Cooley, P. \& Burke, D. (2006). Strategies for mitigating an influenza pandemic. Nature 442(7101), 448-452.

Gümüşgül, O. \& Aydoğan, R. (2020), Yeni Tip Koronavirüs-Covid 19 Kaynaklı Evde Geçirilen Boş Zamanların Ev İçi Rekreatif Oyunlar ile Değerlendirilmesi. Spor Eğitim Dergisi, 4 (1), 107 114.

Hair, J.F.J., Anderson, R.E., Tatham, R.L., Black, W.C., 1998. Multivariate Data Analysis, 5th edn, Prentice Hall, Upper Saddle River.

Hampson, R.B. \& Beaver, W.R. (1993). Measuring family competence: The Beavers systems model. In Walsh, F. (Ed.), Normal family processes, (2nd ed.) New York: Guilford Press.

Hocker, J.L. \& Wilmot, W.W. (1995), Interpersonal Conflict, Fourth Edition, Wm,C, Madison: Brown Benchmark Communications, Inc.

Kluwer, E. (2020). Families in time of Corona. (Erişim Tarihi: 11.06.2020). https://nias.knaw.nl/food-for-thought/families-in-times-of-corona/ 
Mcloyd, V. (1990). The Impact Of Economic Hardship On Black Families And Children. Psychological Distress, Parenting And Socioemotional Development. Child Development. 61:311-346.

Miller, L., \& Tucker, C. (1993). The Intrahousehold Communications Study: A Typology of Family Cohesion. In American Statistical Association Proceedings of the Section on Survey Research Methods, 936-941.

Moos, R. (1974). The social climate scales: An overview. Palo Alto, CA: Consulting Psychologists Press.

Moos, R.H.\& Moos, B.S.(1981).Manual fort he Family Environment Scale.Palo Alto, CA:Consulting Psychologists Press.

Nohe, C., Meier, L. L., Sonntag, K., \& Michel, A. (2015). The chicken or the egg? A meta-analysis of panel studies of the relationship between work-family conflict and strain. Journal of Applied Psychology, 100, 522-536. https://doi.org/10.1037/a0038012

NSPCC. (2020). Arguments, conflict and family tension during coronavirus (Covid-19). (Erişim Tarihi: 11.06.2020). https://www.nspcc.org.uk/keeping-children-safe/support-forparents/arguments-conflict-family-tension-coronavirus-lockdown.

Özatay, F. \& Sak G. (2020a). Covid-19'un Ekonomik Sonuçlarını Yönetebilmek İçin Ne Yapılabilir?, TEPAV Politika Notu No, 202006.

Özatay F. \& Sak G. (2020b). Covid-19 Nedeniyle Sokağa Çıkma Yasă̆ı Uygulanırsa, TEPAV Politika Notu No, 202008.

Simon, J.B., Murphy, J.J., and Smith, S.M. (2005). Understanding and Fostering Family Resilience. He Family Journal: Counselling and Theraphy For Couples And Families, 13(4), 427-436.

T.C. Sağlık Bakanlığı Halk Sağlığı Genel Müdürlüğü. (2020). Covid-19 (SARS-CoV-2 Enfeksiyonu) Genel Bilgiler, Epidemioloji ve Tanı. Bilimsel Danışma Kurulu Çalışması. (Erişim Tarihi: 11.06.2020). https://covid19bilgi.saglik.gov.tr/depo/rehberler/Covid-19rehberi/Covid-19_rehber1_genel_bilgiler_epidemiyoloj1_ve_tanı.pdf.

Türkiye Psikiyatri Derneği Ruhsal Travma ve Afet Çalışma Birimi. (2020). Karantinanın Ruhsal Etkileri ve Koruyucu Önlemler. (Erişim Tarihi: 11.06.2020). https://www.psikiyatri.org.tr/tpddata/uploads/files/karantinacovid.pdf.

Ural, A., \& Kılıç, İ. (2011). Bilimsel Araştırma Süreci ve SPSS ile Veri Analizi: SPSS 10.0-12.0 For Windows. Ankara: Detay Yayınc1lik.

Usluer, S. (1989). The realibity and the validity of the Turkish Family Environment Questionnare, (Master Thesis), Bogaziçi Universitesi.

Ümmet, D. (2007). Üniversite öğrencilerinde sosyal kaygının cinsiyet rolleri ve aile ortamı bağlamında incelenmesi (Yayınlanmamış yüksek lisans tezi), Marmara Üniversitesi.

WHO (2020). Covid-19 Strategy Update. 